Prepared in cooperation with the Rhode Island Emergency Management Agency and the U.S. Army Corps of Engineers

\title{
Flood-Inundation Maps for the Pawtuxet River in West Warwick, Warwick, and Cranston, Rhode Island
}

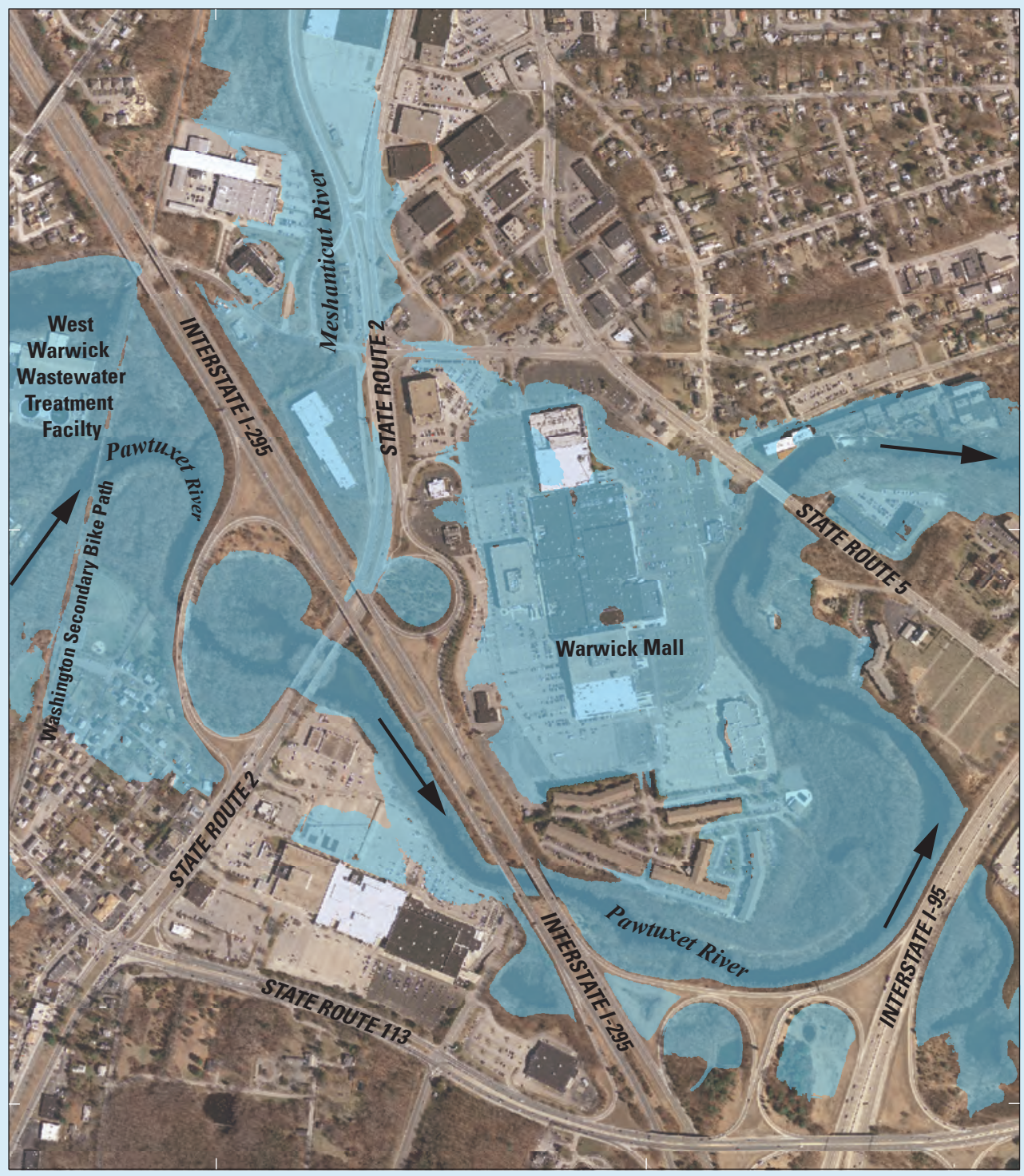

Scientific Investigations Report 2018-5043 
Cover. Flood-inundation map for a reach of the Pawtuxet River in Warwick, Rhode Island, corresponding to a stage of 21.0 feet, gage datum, approximately depicting the March 31, 2010, peak flood stage of 20.79 feet at U.S. Geological Survey Pawtuxet River at Cranston, Rhode Island, streamgage 01116500. 


\section{Flood-Inundation Maps for the Pawtuxet River in West Warwick, Warwick, and Cranston, Rhode Island}

By Gardner C. Bent and Pamela J. Lombard

Prepared in cooperation with the Rhode Island Emergency Management Agency and the U.S. Army Corps of Engineers

Scientific Investigations Report 2018-5043 


\section{U.S. Department of the Interior \\ RYAN K. ZINKE, Secretary}

\section{U.S. Geological Survey James F. Reilly II, Director}

\section{U.S. Geological Survey, Reston, Virginia: 2018}

For more information on the USGS - the Federal source for science about the Earth, its natural and living resources, natural hazards, and the environment-visit https://www.usgs.gov or call 1-888-ASK-USGS.

For an overview of USGS information products, including maps, imagery, and publications, visit https://store.usgs.gov.

Any use of trade, firm, or product names is for descriptive purposes only and does not imply endorsement by the U.S. Government.

Although this information product, for the most part, is in the public domain, it also may contain copyrighted materials as noted in the text. Permission to reproduce copyrighted items must be secured from the copyright owner.

Suggested citation:

Bent, G.C., and Lombard, P.J., 2018, Flood-inundation maps for the Pawtuxet River in West Warwick, Warwick, and Cranston, Rhode Island: U.S. Geological Survey Scientific Investigations Report 2018-5043, 16 p., https://doi.org/10.3133/sir20185043.

ISSN 2328-0328 (online) 


\section{Acknowledgments}

The authors thank the Rhode Island Water Resources Board for funding the operation and maintenance of the U.S. Geological Survey (USGS) streamgage at Pawtuxet River at Cranston, Rhode Island, 01116500, used for this study. Special thanks are given to the National Weather Service for providing forecasted river stages for the streamgage and their continued support of the USGS flood-inundation mapping program. The authors thank the Federal Emergency Management Agency for providing the hydraulic model used in the 2015 effective Flood Insurance Studies for Kent and Providence Counties, Rhode Island, and the U.S. Army Corps of Engineers personnel for surveying the former Pawtuxet Falls dam area in April 2016 and entering surveyed data into the hydraulic model.

The authors also thank USGS field personnel for surveying hydraulic structures and cross sections on the Pawtuxet River during 2011 and August 2016 and USGS personnel for flood map preparation. 



\section{Contents}

Acknowledgments ……...................................................................................................................

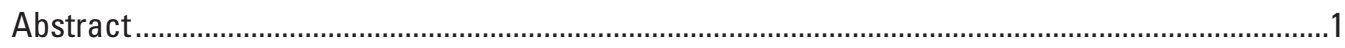

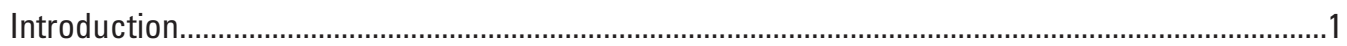

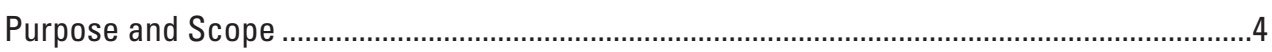

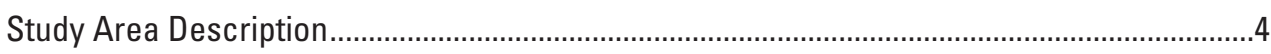

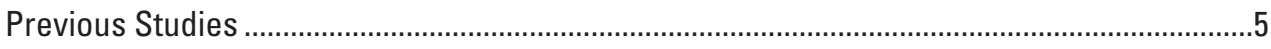

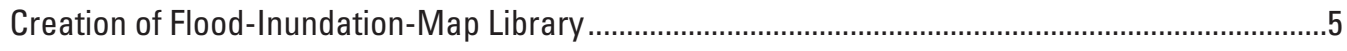

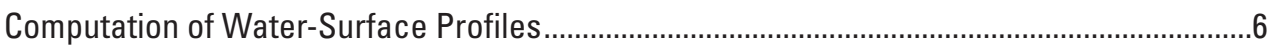

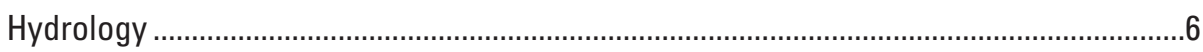

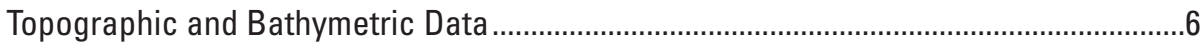

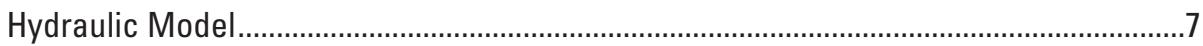

Development of Water-Surface Profiles .........................................................................

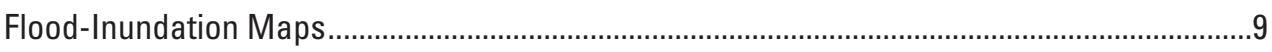

Flood-Inundation Map Delivery .......................................................................................13

Disclaimer For Flood-Inundation Maps......................................................................13

Uncertainties and Limitations Regarding Use of Flood-Inundation Maps ......................13

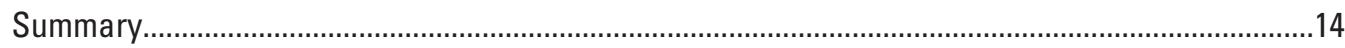

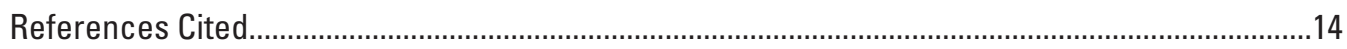

\section{Figures}

1. Map showing location of the Pawtuxet River study reach in West Warwick, Warwick, and Cranston, Rhode Island, and U.S. Geological Survey Pawtuxet River at Cranston streamgage 01116500 .

2. Graphs showing cumulative precipitation, stage, and streamflow data for the Pawtuxet River, Rhode Island, during the floods of February 23, 2010, through April 5, 2010: A, cumulative daily precipitation at the National Weather Service climatological station at Providence T.F. Green Airport, Warwick, Rhode Island, B, stage, and C, streamflow at U.S. Geological Survey Pawtuxet River at Cranston, Rhode Island, streamgage 01116500.

3. Flood-inundation map for a reach of the Pawtuxet River in Warwick, Rhode Island, corresponding to a stage of 21.0 feet, gage datum, approximately depicting the March 31, 2010, peak flood stage of 20.79 feet at U.S. Geological Survey Pawtuxet River at Cranston, Rhode Island, streamgage 01116500.

\section{Tables}

1. Description of U.S. Geological Survey Pawtuxet River at Cranston, Rhode Island, streamgage 01116500 .

2. Peak-discharge estimates for selected annual exceedance probabilities at the U.S. Geological Survey Pawtuxet River at Cranston, Rhode Island, streamgage 01116500, using annual peak discharges for water years 1940-2015.

3. Estimated discharges for selected locations used in the hydraulic model of the Pawtuxet River in West Warwick, Warwick, and Cranston, Rhode Island, and the corresponding discharges, stages, and water-surface elevations at U.S. Geological Survey Pawtuxet River at Cranston, Rhode Island, streamgage 01116500. 
4. Description of bridge crossings, dams, and a levee in the hydraulic model of the Pawtuxet River in West Warwick, Warwick, and Cranston, Rhode Island

5. Differences between 15 simulated water-surface elevations and stage elevations at 1-foot intervals from 8.0 to 22.0 feet for U.S. Geological Survey Pawtuxet River at Cranston, Rhode Island, streamgage 01116500

6. Differences between the hydraulic model simulated water-surface elevations for the March 31, 2010, floodflows and the surveyed high-water-mark elevations on the Pawtuxet River in West Warwick, Warwick, and Cranston, Rhode Island.

7. Stage, discharge, and approximate annual exceedance probability at U.S. Geological Survey Pawtuxet River at Cranston, Rhode Island, streamgage 01116500 for profiles mapped on the Pawtuxet River in West Warwick, Warwick, and Cranston, Rhode Island. 


\section{Conversion Factors}

U.S. customary units to International System of Units

\begin{tabular}{|c|c|c|}
\hline Multiply & By & To obtain \\
\hline \multicolumn{3}{|c|}{ Length } \\
\hline inch (in.) & 2.54 & centimeter $(\mathrm{cm})$ \\
\hline foot $(\mathrm{ft})$ & 0.3048 & meter $(\mathrm{m})$ \\
\hline mile (mi) & 1.609 & kilometer $(\mathrm{km})$ \\
\hline \multicolumn{3}{|c|}{ Area } \\
\hline square mile $\left(\mathrm{mi}^{2}\right)$ & 2.590 & square kilometer $\left(\mathrm{km}^{2}\right)$ \\
\hline \multicolumn{3}{|c|}{ Flow rate } \\
\hline cubic foot per second $\left(\mathrm{ft}^{3} / \mathrm{s}\right)$ & 0.02832 & cubic meter per second $\left(\mathrm{m}^{3} / \mathrm{s}\right)$ \\
\hline
\end{tabular}

\section{Datum}

Vertical coordinate information is referenced to either stage (the height above an arbitrary datum established at a streamgage) or to the North American Vertical Datum of 1988 (NAVD 88).

Horizontal coordinate information is referenced to the North American Datum of 1983 (NAD 83).

Elevation, as used in this report, refers to distance above the vertical datum.

\section{Abbreviations}

$\begin{array}{ll}\text { AEP } & \text { annual exceedance probability } \\ \text { AHPS } & \text { Advanced Hydrologic Prediction Service } \\ \text { DEM } & \text { digital elevation model } \\ \text { DGPS } & \text { differential global positioning system } \\ \text { FEMA } & \text { Federal Emergency Management Agency } \\ \text { FIS } & \text { Flood Insurance Study } \\ \text { GIS } & \text { geographic information system } \\ \text { HWM } & \text { high-water mark } \\ \text { lidar } & \text { light detection and ranging } \\ \text { NGS } & \text { National Geodetic Survey } \\ \text { NWIS } & \text { National Water Information System } \\ \text { NWS } & \text { National Weather Service } \\ \text { RTK } & \text { real-time kinematic } \\ \text { USACE } & \text { U.S. Army Corps of Engineers } \\ \text { USGS } & \text { U.S. Geological Survey } \\ \text { WWTF } & \text { wastewater treatment facility }\end{array}$





\title{
Flood-Inundation Maps for the Pawtuxet River in West Warwick, Warwick, and Cranston, Rhode Island
}

\author{
By Gardner C. Bent and Pamela J. Lombard
}

\section{Abstract}

A series of 15 digital flood-inundation maps was developed for a 10.2-mile reach of the Pawtuxet River in the municipalities of West Warwick, Warwick, and Cranston, Rhode Island, by the U.S. Geological Survey (USGS), in cooperation with the Rhode Island Emergency Management Agency and the U.S. Army Corps of Engineers. The coverage of the maps extends downstream from Natick Pond dam near State Route 33/Providence Street bridge in West Warwick to the mouth of the river at Pawtuxet Cove (Broad Street bridge) on the border between Cranston and Warwick, R.I. A one-dimensional step-backwater hydraulic model created and calibrated for the Federal Emergency Management Agency Flood Insurance Studies for Kent and Providence Counties in 2015 was updated for this study. The updated hydraulic model reflects the removal of the Pawtuxet Falls dam during 2011 and the raised elevation of a levee surrounding the Warwick Sewer Authority wastewater treatment facility during 201417. The hydraulic model was calibrated by using the current (2018) stage-discharge relation at the USGS Pawtuxet River at Cranston, Rhode Island, streamgage (01116500) and documented high-water marks from the March 31, 2010, flood, which had a peak flow greater than the estimated 0.2-percent annual exceedance probability floodflow.

The hydraulic model was used to compute water-surface profiles for 15 flood stages at 1-foot (ft) intervals referenced to the USGS Pawtuxet River at Cranston, Rhode Island, streamgage (01116500) and ranging from $8.0 \mathrm{ft}(15.2 \mathrm{ft}$, North American Vertical Datum of 1988), which is the National Weather Service Advanced Hydrologic Prediction Service flood category "action stage," to $22.0 \mathrm{ft}(29.2 \mathrm{ft}$, North American Vertical Datum of 1988), which is the maximum stage of the stage-discharge relation at the streamgage and exceeds the National Weather Service Advanced Hydrologic Prediction Service flood category "major flood stage" of $13.0 \mathrm{ft}$. The simulated water-surface profiles were combined with a geographic information system digital elevation model derived from light detection and ranging (lidar) data with a $1.0-\mathrm{ft}$ vertical accuracy to create flood-inundation maps. The flood-inundation maps depict estimates of the areal extent and depth of flooding corresponding to 15 selected flood stages at the streamgage. The flood-inundation maps depict only riverine flooding and do not depict any tidal backwater or coastal storm surge that might occur in the lower part of the river reach. The flood-inundation maps can be accessed through the USGS Flood Inundation Mapping Science website at https://water.usgs.gov/osw/flood_inundation. Near-real-time stages and discharges at the Pawtuxet River streamgage can be obtained from the USGS National Water Information System at https://waterdata.usgs.gov/. The National Weather Service Advanced Hydrologic Prediction Service provides flood forecasts of stage for this site (CRAR1) at https:/water.weather. gov/ahps/.

The availability of flood-inundation maps referenced to current and forecasted water levels at the USGS Pawtuxet River at Cranston, Rhode Island, streamgage (01116500) can provide emergency management personnel and residents with information that is critical for flood response activities, such as evacuations and road closures, and postflood recovery efforts. The flood-inundation maps are nonregulatory but provide Federal, State, and local agencies and the public with estimates of the potential extent of flooding during flood events.

\section{Introduction}

During late February through early April 2010, the State of Rhode Island, particularly the Pawtuxet River Basin, was affected by major flooding. This flooding was characterized as the worst in 200 years. Damages were estimated to be upward of \$100 million, and the entire State was included in the President's emergency declaration (Rhode Island severe storms and flooding EM-3311) on March 30, 2010 (Zarriello and others, 2014). Flooding along the Pawtuxet River affected critical infrastructure, including U.S. Interstate I-95; Cranston, Warwick Sewer Authority, and West Warwick wastewater treatment facilities (WWTFs); and the Warwick Mall (Brown University, 2011) (fig. 1). Numerous businesses and homes along the Pawtuxet River also were flooded.

Four precipitation events occurred from February 23 through March 30, 2010, totaling 20.36 inches (fig. $2 A$ ) at the Providence T.F. Green Airport, Warwick, Rhode Island (fig. 1; data from Global Historical Climatology Network-Daily 


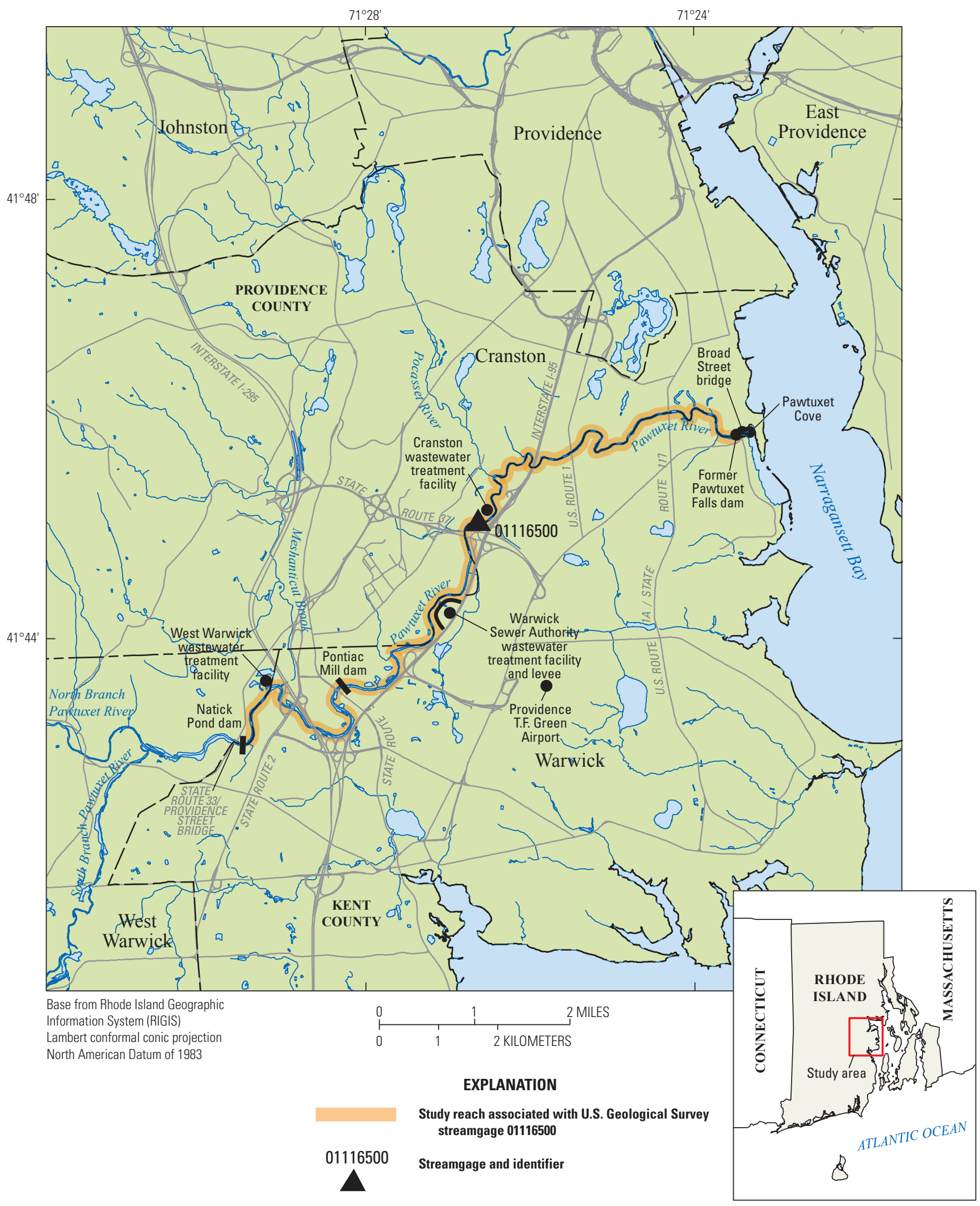

Figure 1. Location of the Pawtuxet River study reach in West Warwick, Warwick, and Cranston, Rhode Island, and U.S. Geological Survey Pawtuxet River at Cranston streamgage 01116500. 

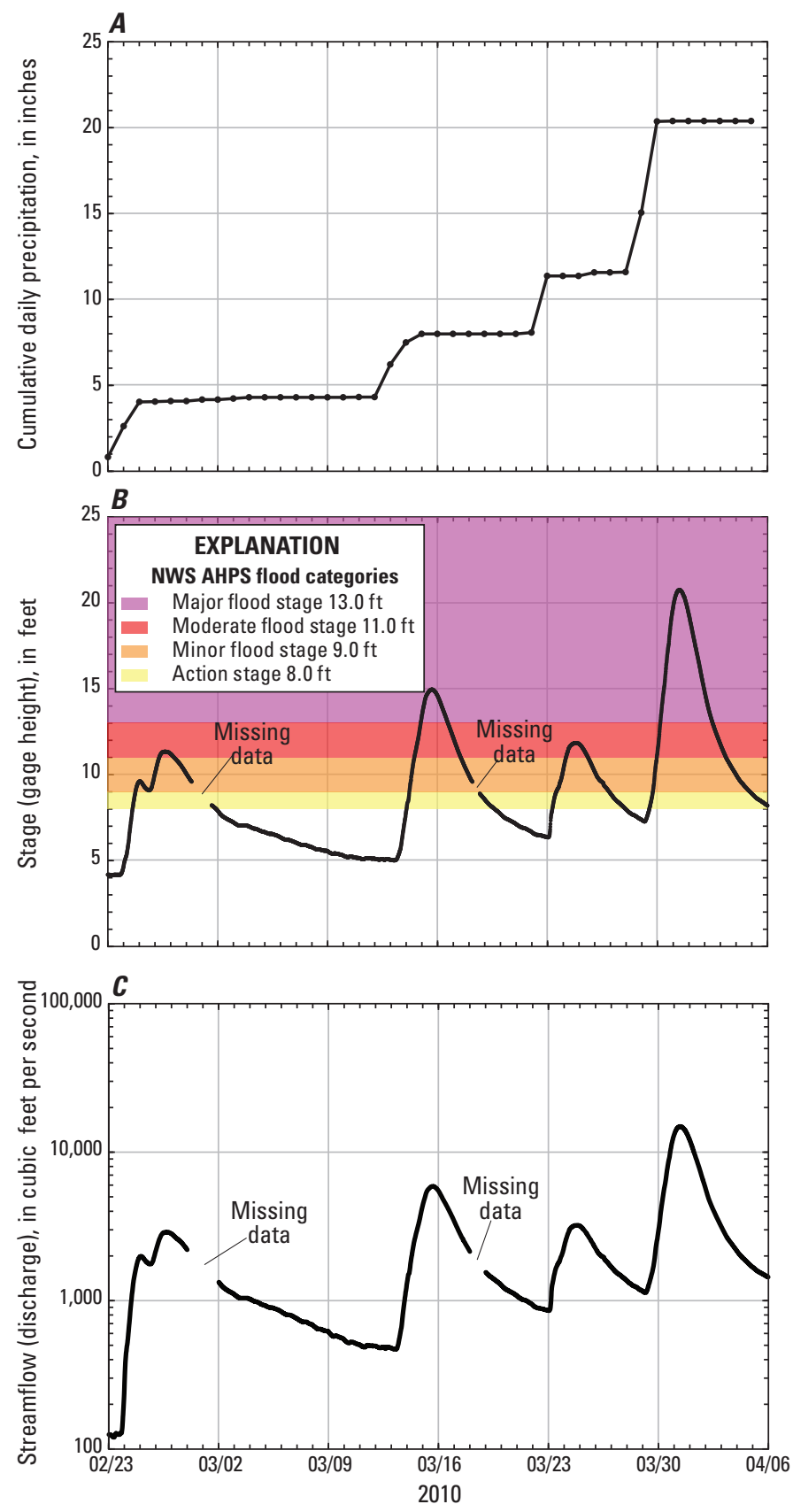

Figure 2. Cumulative precipitation, stage, and streamflow data for the Pawtuxet River, Rhode Island, during the floods of February 23, 2010, through April 5, 2010: A, cumulative daily precipitation at the National Weather Service climatological station at Providence T.F. Green Airport, Warwick, Rhode Island, B, stage, and C, streamflow at U.S. Geological Survey Pawtuxet River at Cranston, Rhode Island, streamgage 01116500 . NWS, National Weather Service; AHPS, Advanced Hydrologic Prediction Service; ft, foot.
[GHCND] station number USW00014765; National Oceanic and Atmospheric Administration, 2010). Precipitation from each of the four events totaled from about 3.2 to 8.9 inches, resulting in a series of four floods. The final flood culminated with a new peak stage and flow of record at the U.S. Geological Survey (USGS) streamgage on the Pawtuxet River at Cranston, R.I., (01116500; hereafter referred to as the Pawtuxet River streamgage) on March 31, 2010 (figs. 2B and $C$ ) (U.S. Geological Survey, 2016). The new peak of record has a stage of 20.79 feet (ft) and a discharge of 14,900 cubic feet per second $\left(\mathrm{ft}^{3} / \mathrm{s}\right)$ (table 1$)$. The stage was more than $6 \mathrm{ft}$ higher and the discharge about 2.7 times greater than the previous peak of record (the previous peak stage was $14.50 \mathrm{ft}$ and discharge was $5,440 \mathrm{ft}^{3} / \mathrm{s}$ on June 7,1982 , for water years $\left.{ }^{1} 1940-2009\right)$. The March 31, 2010 peak flow of 14,900 $\mathrm{ft}^{3} / \mathrm{s}$ was greater than the estimated 0.2 -percent annual exceedance probability floodflow (table 7 of Zarriello and others, 2012).

Prior to this study, emergency responders in the municipalities of West Warwick, Warwick, and Cranston relied on four information sources to make decisions on how to best alert the public and mitigate damages during floods. Two of these sources are the Kent County and Providence County Federal Emergency Management Agency (FEMA) Flood Insurance Studies (FISs; Federal Emergency Management Agency, 2015a and 2015b, respectively). The third source of information is the Pawtuxet River streamgage, just downstream from the westbound State Route (Rt.) 37 bridge (fig. 1), which provides stage, discharge, and annual peak flow data from December 1939 to the present (2018) (U.S. Geological Survey, 2016). The fourth source of flood-related information is the National Weather Service (NWS) Advanced Hydrologic Prediction Service (AHPS), which issues flood forecasts of stage for the Pawtuxet River streamgage (CRAR1; National Weather Service, 2016).

Although the current stage at a USGS streamgage is particularly useful for residents in the immediate vicinity of a streamgage, it is of limited use to residents farther upstream or downstream because the water-surface elevation is not constant along the entire stream reach. Knowledge of a water level at a streamgage is difficult to translate into depth and areal extent of flooding at points distant from the streamgage. One way to address these informational gaps is to produce a library of flood-inundation maps that are referenced to the stages recorded at a USGS streamgage. By referring to the appropriate map, emergency responders can discern the severity of flooding (depth of water and areal extent), identify roads that are or will soon be flooded, and make plans for notification or evacuation of residents in harm's way for some distance upstream and downstream from the streamgage. In addition, the capability to visualize the potential extent of flooding has been shown to motivate residents to take precautions and heed warnings that they previously might have disregarded. In 2016-17, the USGS, in cooperation with the

${ }^{1}$ A water year is the 12-month period from October 1 through September 30 of the following year and is designated by the calendar year in which it ends. 
Table 1. Description of U.S. Geological Survey Pawtuxet River at Cranston, Rhode Island, streamgage 01116500.

[Streamgage location is shown in figure 1. USGS, U.S. Geological Survey; NAD 83, North American Datum of 1983; NAVD 88, North American Vertical Datum of 1988; $\mathrm{mi}^{2}$, square mile; ft, foot; $\mathrm{ft}^{3} / \mathrm{s}$, cubic foot per second]

\begin{tabular}{lc}
\hline & Site description \\
\hline USGS streamgage name & Pawtuxet River at Cranston, Rhode Island \\
USGS streamgage number & 01116500 \\
Drainage area & $200 \mathrm{mi}^{2}$ \\
Latitude (decimal degrees, NAD 83) & 41.75093 \\
Longitude (decimal degrees, NAD 83) & -71.44506 \\
Period of peak-flow record, in water years ${ }^{1}$ & $1940 \mathrm{to} \mathrm{present}$ \\
Maximum stage (gage datum [elevation, above NAVD 88]); date & $20.79 \mathrm{ft}[27.99 \mathrm{ft}] ;$ March 31, 2010 \\
Maximum discharge; date & $14,900 \mathrm{ft} / \mathrm{s}$; March 31, 2010
\end{tabular}

\footnotetext{
${ }^{1} \mathrm{~A}$ water year is the 12-month period from October 1 of one year through September 30 of the following year and is designated by the calendar year in
} which it ends.

Rhode Island Emergency Management Agency and the U.S. Army Corps of Engineers (USACE), conducted a project to produce a library of flood-inundation maps for the Pawtuxet River in West Warwick, Warwick, and Cranston, R.I., using a hydraulic model.

\section{Purpose and Scope}

This report describes the development of a hydraulic model and creation of a series of 16 flood-inundation maps for a 10.2-mile (mi) reach of the Pawtuxet River downstream from the Natick Pond dam to Pawtuxet Cove (its mouth at Narragansett Bay; fig. 1) in West Warwick, Warwick, and Cranston, R.I. The maps, in 1-ft increments, cover a range in stage from 8.0 to $22.0 \mathrm{ft}$ (gage datum) at the Pawtuxet River streamgage. The maps begin at the NWS AHPS flood category "action stage" of $8.0 \mathrm{ft}$ and go to the maximum stage of the stage-discharge relation of $22.0 \mathrm{ft}$, which exceeds the maximum recorded peak stage $(20.79 \mathrm{ft}$ on March 31, 2010). The flood-inundation maps depict only riverine flooding; they do not depict any tidal backwater or coastal storm surge that might occur in the lower part of the river reach. The flood-inundation maps were developed for display on the USGS Flood Inundation Mapper website (https://wimcloud.usgs.gov/apps/FIM/

FloodInundationMapper.html).

\section{Study Area Description}

The Pawtuxet River Basin covers an area of about 232 square miles $\left(\mathrm{mi}^{2}\right)$ in central Rhode Island, and the
Pawtuxet River discharges into Pawtuxet Cove at the northern end of Narragansett Bay just south of the city of Providence (fig. 1). The Pawtuxet River Basin lies within three counties - Providence, Kent, and a small part of Washington. The Pawtuxet River begins at the confluence of the North Branch Pawtuxet River and the South Branch Pawtuxet River and flows generally northeasterly until it reaches Pawtuxet Cove in Narragansett Bay. The Pawtuxet River is a low-gradient river that flows about 11.2 mi through urbanized areas of Rhode Island with commercial and industrial land uses and mediumto high-density residential housing. The Pawtuxet River flows through the town of West Warwick, and the cities of Warwick and Cranston, R.I., which in 2010 had populations of 29,191; 82, 672; and 80,387, respectively (U.S. Census Bureau, 2016).

The study reach begins downstream from the Natick Pond dam, which is located about 1.0 mi downstream from the confluence of the North Branch Pawtuxet River and the South Branch Pawtuxet River (fig. 1). The 10.2-mi study reach has several tributaries; the largest ones are Meshanticut Brook (13.6- $\mathrm{mi}^{2}$ drainage area) and Pocasset River (20.6- $\mathrm{mi}^{2}$ drainage area). The Pawtuxet River streamgage (01116500) is $4.8 \mathrm{mi}$ upstream from the end of the study reach (downstream from the Broad Street bridge) and $5.4 \mathrm{mi}$ downstream from the beginning of the study reach (downstream from Natick Pond dam) (fig. 1). The streamgage is associated with a drainage area of $200 \mathrm{mi}^{2}$. The study reach is crossed by 13 road bridges, 4 railroad bridges ( 2 active, 1 abandoned, and 1 bike path), and 2 dams. The Natick Pond dam and the State Rt. 33/Providence Street bridge are upstream from (outside of) the study reach. The Pawtuxet Falls dam just upstream from the Broad Street bridge near the mouth of the river was removed in 2011, and a levee around the Warwick Sewer Authority WWTF was 
raised during 2014-17 to be higher than the 0.2-percent annual exceedance probability flood (fig. 1).

The water-surface elevations of the lower part of the Pawtuxet River study reach from about U.S. Rt. 1A/State Rt. 117/Warwick Avenue to Pawtuxet Cove (fig. 1) could be affected by tidal backwater from high tides in Narragansett Bay. However, from several field observations, it appears that when flows are greater than about $1,000 \mathrm{ft}^{3} / \mathrm{s}$ (stage of about $6.83 \mathrm{ft}$ at gage datum) at the Pawtuxet River streamgage, there is little to no effect of tidal backwater at normal (non-storm affected) high tide upstream from the former Pawtuxet Falls dam (removed in 2011), which was about $100 \mathrm{ft}$ upstream from the Broad Street bridge (Andrew Massey, U.S. Geological Survey, oral commun., 2016). The FEMA FIS for Kent County and the FIS for Providence County (Federal Emergency Management Agency, 2015a and 2015b, respectively) show tidal backwater for the 1-percent annual exceedance probability (AEP) water-surface elevation extending upstream from Pawtuxet Cove about $800 \mathrm{ft}$ (about $440 \mathrm{ft}$ upstream from the Broad St. bridge), but with the Pawtuxet River dam present. A study by the Rhode Island Coastal Resources Management Council (2017) depicted tidal surges from the hurricanes of 1938 and 1954 extending up the Pawtuxet River to just downstream from the Warwick Sewer Authority WWTF and to about the Pawtuxet River streamgage, respectively. The study also depicted the tidal surge of Hurricane Bob (1991) extending up the Pawtuxet River to about 5,400 ft upstream from the U.S. Rt. 1A/State Rt. 117/Warwick Avenue bridge. The effects of tidal backwater and storm surge on water-surface elevations were beyond the scope of this project, so the flood-inundation maps associated with this project depict only riverine flooding and do not account for (nor depict) any inundation that could result from possible tidal backwater or coastal storm surge in the lower part of the river reach.

\section{Previous Studies}

Several studies were conducted in the Pawtuxet River Basin by the USGS after the late February through early April floods in Rhode Island. Fifty high-water marks were flagged and surveyed along the main stem of the Pawtuxet River by the USGS and the USACE following the floods (tables 1-1 and 1-2 of Zarriello and Bent, 2011). The magnitudes of the floodflows for selected AEPs at the Pawtuxet River streamgage were calculated by using annual peak flow data for water years 1940 through 2010 (table 7 of Zarriello and others, 2012) but were updated for this study with data from water years 1940 to 2015 (table 2) using the methods described in England and others (2018). The USGS developed a hydraulic model for the Pawtuxet River in 2013 (Zarriello and others, 2014) as part of a study to compare simulated flood elevations to those observed in 2010 (Zarriello and Bent, 2011). The model was calibrated with selected high-water marks from the March 31, 2010, flood (Zarriello and Bent, 2011). The hydraulic model was then used by USGS for the FEMA FISs for Kent and Providence Counties in 2015 (Federal Emergency Management Agency, 2015a and 2015b, respectively).

Three studies by Kleinschmidt Energy and Water Resources Consultants (2005), Milone \& MacBroom, Inc. (2008), and EA Engineering, Science, and Technology, Inc. (2010) evaluated the restoration of native ecology, fisheries, and wetlands of the lower Pawtuxet River (fig. 1). These three studies were considered as part of the removal of the Pawtuxet Falls dam in August 2011.

\section{Creation of Flood-Inundation-Map Library}

The USGS has standardized the procedures for creating flood-inundation maps for flood-prone communities so that the process followed and products produced are similar across studies. Tasks specific to development of the flood maps for the Pawtuxet River include (1) modification of the Pawtuxet River hydraulic model that was used for the FEMA 2015 FISs for Kent and Providence Counties (FEMA, 2015a and 2015 b, respectively), (2) verification of energy-loss factors (roughness coefficients) in the stream channel and flood plain, (3) computation of water-surface profiles with the USACE HEC-RAS version 5.0.3 computer program (U.S. Army

Table 2. Peak-discharge estimates for selected annual exceedance probabilities at the U.S. Geological Survey Pawtuxet River at Cranston, Rhode Island, streamgage 01116500, using annual peak discharges for water years 1940-2015.

[USGS, U.S. Geological Survey; $\mathrm{mi}^{2}$, square mile; $\mathrm{ft}^{3} / \mathrm{s}$, cubic foot per second; \%, percent; RI, Rhode Island]

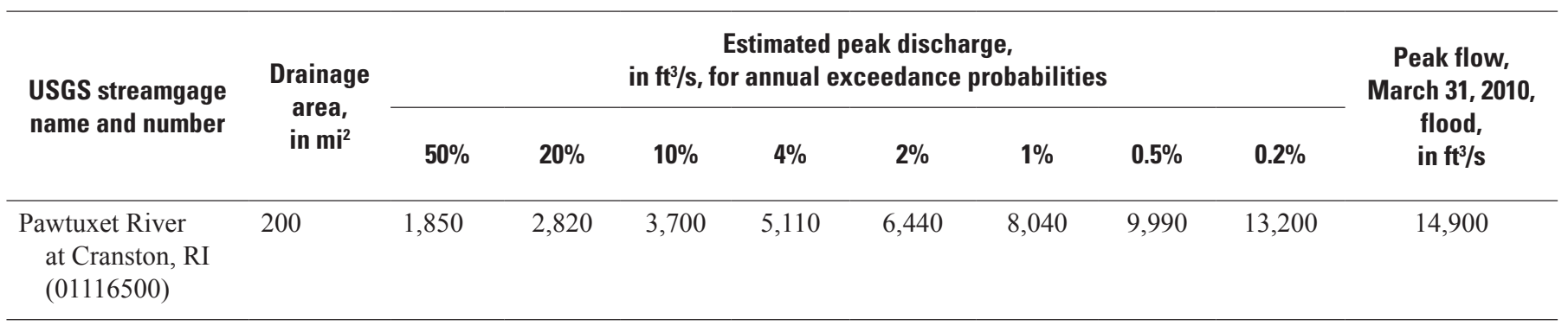


Corps of Engineers, 2016) for the selected 1-ft stage intervals at the Pawtuxet River streamgage, (4) production of floodinundation maps corresponding to each modeled flood profile using the USACE HEC-GeoRAS computer program (U.S. Army Corps of Engineers, 2009) and a geographic information system (GIS), and (5) preparation of the maps as shapefile polygons that depict the areal extent of flood inundation and as depth grids that provide the depth of floodwaters for display on a USGS flood-inundation mapping application.

\section{Computation of Water-Surface Profiles}

The water-surface profiles used to produce the 15 floodinundation maps in this study were computed by the HECRAS version 5.0.3 software (U.S. Army Corps of Engineers, 2016). HEC-RAS is a one-dimensional step-backwater model for simulation of water-surface, and it includes options for computing steady-state (gradually varied) or unsteady-state flow.

\section{Hydrology}

The study reach includes the Pawtuxet River streamgage, which has been in operation since December 1939 (fig. 1; table 1). The streamgage is $4.8 \mathrm{mi}$ upstream from the mouth of the river and $0.1 \mathrm{mi}$ downstream from the State Route 37 westbound bridge crossing. The river stage is measured every 15 minutes, transmitted hourly via satellite, and is available on the USGS National Water Information System (NWIS) website (U.S. Geological Survey, 2016). River stage data from this streamgage are referenced to a local datum but can be converted to water-surface elevations referenced to the North American Vertical Datum of 1988 (NAVD 88) by adding $7.20 \mathrm{ft}$. Continuous records of streamflow are computed from a stage-discharge relation (rating curve) developed through concurrent stage and streamflow measurements collected since December 1939. The current (2018) rating curve, 43.1, was used for this study.

The discharges input into the model simulations (table 3) are from the current (2018) stage-discharge relation (rating curve 43.1) and correspond to the target stages. Stage-discharge relation rating curve 43.1 is the same as rating curve 43 from a stage of 3.20 to $22.00 \mathrm{ft}$; rating curve 43 has been in effect from February 23, 2010 to July 31, 2016. The upper end of the rating curve is based on high-flow measurements (U.S. Geological Survey, 2016) made during the late February through early April 2010 floods.

Two tributaries-Meshanticut Brook and Pocasset River-join the Pawtuxet River within the 10.2-mile study reach (fig. 1). The streamgage-derived discharges were adjusted as necessary to account for tributary inflows (table 3 ). The adjustments were estimated by applying a drainage-area ratio method (Johnstone and Cross, 1949) to the discharges at each of the 1-ft stage intervals from 8.0 to $22.0 \mathrm{ft}$ and the March 31, 2010, floodflow at the Pawtuxet River streamgage.
The flows were transferred upstream and downstream by using the following equation:

$$
Q_{u}=Q_{g}\left(\frac{D A_{u}}{D A_{g}}\right)^{e},
$$

where

$Q_{u} \quad$ is the streamflow at an ungaged location, in cubic feet per second;

$Q_{g} \quad$ is the streamflow at a gaged location, in cubic feet per second;

$D A_{u} \quad$ is the drainage area at an ungaged location, in square miles;

$D A_{g} \quad$ is the drainage area at a gaged location, in square miles; and

$e \quad$ is the exponent of the drainage-area-only regional regression equations (table 16 of Zarriello and others, 2012) for the appropriate AEP.

The 50- to 0.2-percent AEP floodflows at the Pawtuxet River streamgage (table 2) that were closest to the discharge value for each of the 1-ft stage intervals from 8.0 to $22.0 \mathrm{ft}$ and the March 31, 2010, floodflow were matched to determine the associated exponent, as shown in Zarriello and others (2012, table 16) for equation 1 . For example, the discharge for a stage of $21.0 \mathrm{ft}$ at the streamgage and in the reach downstream from the confluence with Meshanticut Brook, 15,300 $\mathrm{ft}^{3} / \mathrm{s}$ (table 3 ), is closest to 0.2-percent AEP flow of 13,200 $\mathrm{ft}^{3} / \mathrm{s}$ (table 2), which relates to an exponent of 0.76 for the 0.2 -percent AEP in Zarriello and others (2012, table 16).

\section{Topographic and Bathymetric Data}

All topographic data used in this study are referenced vertically to NAVD 88 and horizontally to the North American Datum of 1983 (NAD 83). Cross-section elevation data were obtained for the Pawtuxet River corridor area from a digital elevation model (DEM) that was derived from the light detection and ranging (lidar) data collected for the northeastern United States (National Oceanic and Atmospheric Administration, 2013a). The lidar data were collected as a part of the American Recovery and Reinvestment Act of 2009, coordinated and contracted through the USGS National Geospatial Technical Operations Center. The lidar data were collected from December 2010 through December 2011 and processed during 2012-13. The original lidar data have a vertical accuracy of $0.49 \mathrm{ft}$ for the bare-earth terrain landcover category and were collected on a 3.28-ft ground sample distance (National Oceanic and Atmospheric Administration, 2013b). By these criteria, the lidar data support the production of 2-ft contours of land surface (Snyder and others, 2014). The final DEM was resampled to a 6.5 -ft grid-cell size to decrease the GIS processing time. By using HEC-GeoRAS, a set of procedures, tools, and utilities for processing geospatial data in Esri ArcGIS (Esri, 2016), elevation data were extracted from 
Table 3. Estimated discharges for selected locations used in the hydraulic model of the Pawtuxet River in West Warwick, Warwick, and Cranston, Rhode Island, and the corresponding discharges, stages, and water-surface elevations at U.S. Geological Survey Pawtuxet River at Cranston, Rhode Island, streamgage 01116500.

[Row shaded gray is the stage and discharge of the March 31, 2010, floodflow. USGS, U.S. Geological Survey; RI, Rhode Island; ft, foot; NAVD 88, North American Vertical Datum of 1988; $\mathrm{ft}^{3} / \mathrm{s}$, cubic foot per second]

\begin{tabular}{|c|c|c|c|c|c|}
\hline \multicolumn{3}{|c|}{$\begin{array}{l}\text { USGS Pawtuxet River at Cranston, RI, streamgage } \\
\qquad(01116500)\end{array}$} & \multicolumn{3}{|c|}{$\begin{array}{l}\text { Estimated discharge at indicated location } \\
\text { used in hydraulic model, in } \mathrm{ft}^{3} / \mathrm{s}\end{array}$} \\
\hline $\begin{array}{l}\text { Stage of water- } \\
\text { surface profile, } \\
\text { in ft referenced to } \\
\text { the gage datum }\end{array}$ & $\begin{array}{c}\text { Water-surface } \\
\text { elevation, in ft above } \\
\text { NAVD } 88\end{array}$ & $\begin{array}{l}\text { 'Discharge, in } \\
\mathrm{ft}^{3} / \mathrm{s}\end{array}$ & $\begin{array}{l}\text { At upstream end } \\
\text { of study reach }\end{array}$ & $\begin{array}{l}\text { Downstream from } \\
\text { confluence with } \\
\text { Meshanticut Brook }\end{array}$ & $\begin{array}{c}\text { Downstream from } \\
\text { confluence with } \\
\text { Pocasset River }\end{array}$ \\
\hline 8.00 & 15.20 & 1,360 & 1,260 & 1,360 & 1,520 \\
\hline 9.00 & 16.20 & 1,710 & 1,580 & 1,710 & 1,910 \\
\hline 10.00 & 17.20 & 2,150 & 1,980 & 2,150 & 2,410 \\
\hline 11.00 & 18.20 & 2,660 & 2,460 & 2,660 & 2,980 \\
\hline 12.00 & 19.20 & 3,300 & 3,050 & 3,300 & 3,690 \\
\hline 13.00 & 20.20 & 4,050 & 3,740 & 4,050 & 4,520 \\
\hline 14.00 & 21.20 & 4,850 & 4,490 & 4,850 & 5,410 \\
\hline 15.00 & 22.20 & 5,900 & 5,460 & 5,900 & 6,570 \\
\hline 16.00 & 23.20 & 7,000 & 6,480 & 7,000 & 7,800 \\
\hline 17.00 & 24.20 & 8,300 & 7,690 & 8,300 & 9,230 \\
\hline 18.00 & 25.20 & 9,824 & 9,100 & 9,820 & 10,900 \\
\hline 19.00 & 26.20 & 11,500 & 10,700 & 11,500 & 12,800 \\
\hline 20.00 & 27.20 & 13,340 & 12,300 & 13,300 & 14,800 \\
\hline 21.00 & 28.20 & 15,330 & 14,200 & 15,300 & 17,000 \\
\hline 22.00 & 29.20 & 17,500 & 16,200 & 17,500 & 19,400 \\
\hline 20.79 & 27.99 & 14,900 & 13,800 & 14,900 & 16,600 \\
\hline
\end{tabular}

${ }^{1}$ Discharge is based on the current (2018) stage-discharge rating curve number 43.1.

the DEM for 184 cross sections and subsequently input to the HEC-RAS model. Because lidar data cannot provide ground elevations below a stream's water surface for the model, channel cross sections were surveyed by USGS field crews during 2011 (Zarriello and others, 2014) and 2016. Additional cross section data were provided by USACE during 2016 (Leanna Martin, U.S. Army Corps of Engineers, written commun., 2016), Kleinschmidt Energy and Water Resources Consultants (2005), Milone \& MacBroom, Inc. (2008), and EA Engineering, Science, and Technology, Inc. (2010). A differential global positioning system (DGPS) with real-time kinematic (RTK) technology was used to derive horizontal locations and the elevation of the water surface at each surveyed cross section and hydraulic structure (bridges and dams) during 2011 and 2016.
The USGS DGPS with RTK technology field surveys were checked periodically against known elevations at National Geodetic Survey (NGS) benchmark sites in Kent County and Providence County, Rhode Island, during 2011 (Zarriello and Bent, 2011) and 2016 (Andrew Massey, U.S. Geological Survey, written commun., 2016). Generally, differences between the USGS and NGS benchmark elevations were less than plus or minus $( \pm) 0.10 \mathrm{ft}$.

Where possible, DEM-generated cross sections were made to coincide with the locations of the within-channel field-surveyed cross sections. In these cases, within-channel data were directly merged with the DEM data. For all other cross sections, the within-channel data were estimated by interpolation from the closest field-surveyed cross section. 


\section{Hydraulic Model}

The hydraulic model for this study was developed by using the HEC-RAS version 5.0.3 software (U.S. Army Corps of Engineers, 2016) and is based on the model used by the USGS for the FEMA FISs for Kent and Providence Counties in 2015 (Federal Emergency Management Agency, 2015a and 2015b, respectively). The hydraulic model reflects the removal of the Pawtuxet Falls dam during 2011 and the raised elevation of a levee surrounding the Warwick Sewer Authority WWTF during 2014-17. Seventeen bridge structures, 2 dams, and 1 levee have the potential to affect water-surface elevations during floods along the stream. The bridge structures include 13 road crossings ( 3 of the 10 crossings - State Route 2, Interstate I-295, and State Route 37-have 2 separate structures each) and 4 railroad bridges ( 2 active, 1 abandoned, and 1 converted to a bike path) (fig. 1, not all structures are shown; table 4). The two dams are the Pontiac Mill dam and an unnamed low-head dam/pipe, about $400 \mathrm{ft}$ downstream from the State Rt. 5/Lambert Lind Highway bridge and about $145 \mathrm{ft}$ downstream from the Pontiac Mill dam, respectively. The unnamed low-head dam/pipe (about $2 \mathrm{ft}$ high) does not affect floodflows and is visible only at low flows. The bridge, dam, and levee geometry data were obtained by USGS field crews during 2011 (Zarriello and others, 2014) and 2016.

Hydraulic analyses require the estimation of energy losses that result from frictional resistance exerted by a channel on flow. These energy losses are quantified by the Manning's roughness coefficient ( $n$-value). Initial (precalibration) $n$-values were selected on the basis of field observations and high-resolution aerial photographs and refined during highwater-mark calibration. Commercial and industrial land uses, and medium- to high-density residential housing areas are present along the riparian corridor of the Pawtuxet River, along with sections that are primarily wooded with fairly dense vegetation. The channel $n$-values range from 0.030 to

Table 4. Description of bridge crossings, dams, and a levee in the hydraulic model of the Pawtuxet River in West Warwick, Warwick, and Cranston, Rhode Island.

[ft, foot; Rt., route; U.S., United States]

\begin{tabular}{|c|c|c|c|}
\hline $\begin{array}{l}\text { River station, } \\
\quad \text { in } \mathrm{ft}^{1}\end{array}$ & Structure & Name & Municipality \\
\hline $51,189.89$ & Bridge & East Avenue & West Warwick and Warwick \\
\hline $49,524.45$ & Bridge & Washington Secondary bike path & West Warwick and Warwick \\
\hline $48,136.76$ & Bridge & Interstate I-295 and State Rt. 2 exit and on ramp & Warwick \\
\hline $47,440.87$ & Bridge & State Rt. 2/Bald Hill Road (southbound) & Warwick \\
\hline $47,360.42$ & Bridge & State Rt. 2/Bald Hill Road (northbound) & Warwick \\
\hline $45,806.50$ & Bridge & Interstate I-295 (southbound) & Warwick \\
\hline $45,652.12$ & Bridge & Interstate I-295 (northbound) & Warwick \\
\hline $40,645.33$ & Bridge & State Rt. 5/Lambert Lind Highway/Greenwich Avenue & Warwick \\
\hline $40,261.48$ & Dam & Pontiac Mill dam & Warwick \\
\hline $40,117.76$ & Dam/pipe & Low-head dam/pipe at Pontiac Mill & Warwick \\
\hline $30,673.00$ to $32,199.00$ & Levee & Warwick Sewer Authority wastewater treatment facility & Warwick/Cranston \\
\hline $25,987.96$ & Bridge & State Rt. 37/Lincoln Avenue Freeway (eastbound) & Warwick/Cranston \\
\hline $25,701.04$ & Bridge & State Rt. 37/Lincoln Avenue Freeway (westbound) & Warwick/Cranston \\
\hline $16,908.42$ & Bridge & Interstate I-95 & Warwick/Cranston \\
\hline $15,888.97$ & Bridge & Amtrak railroad (upstream bridge) & Warwick/Cranston \\
\hline $15,888.97$ & Bridge & Amtrak railroad (downstream bridge) & Warwick/Cranston \\
\hline $14,405.42$ & Bridge & U.S. Rt. 1/Elmwood Avenue & Warwick/Cranston \\
\hline $7,645.32$ & Bridge & Abandoned railroad & Warwick/Cranston \\
\hline $6,063.79$ & Bridge & U.S. Rt. 1A/State Rt. 117/Warwick Avenue & Warwick/Cranston \\
\hline 328.3247 & Bridge & Broad Street & Warwick/Cranston \\
\hline
\end{tabular}

"River station" references the distance upstream to the downstream side of the structure from the most downstream point (starting point) in the hydraulic model. 
0.045 because the channel is mainly sand and gravel with some cobbles interspersed. The $n$-values for the overbanks of the riparian corridor (flood plain) range from 0.050 to 0.100 depending on the openness of the section. Bankfull channeltop widths typically are between about 100 and $200 \mathrm{ft}$ wide. As part of the calibration process, the initial $n$-values were varied by flow and adjusted until the differences between simulated and observed water-surface elevations at the streamgage and at high-water marks were minimized.

The HEC-RAS analysis was done by using the steadystate flow computation option. Steady-state flow data consist of flow regime, boundary conditions, and peak flows that produced water-surface elevations at the streamgage cross section that match target water-surface elevations. These target elevations coincide with even 1-ft increments of stage, referenced to the gage datum. Subcritical (tranquil) flow regime was assumed for the simulations. Normal depth, based on an estimated average streambed slope of $0.00373 \mathrm{ft} / \mathrm{ft}$, was used as the downstream boundary condition for the reach. The HEC-RAS model was calibrated to the stage-discharge relation (rating curve 43.1) at the Pawtuxet River streamgage and to 27 of the 50 flagged and surveyed HWMs for the water surface of the period of record peak flood of March 31, 2010 (Zarriello and Bent, 2011). Only 27 of the 50 HWMs were used for the model calibration because several locations had two or more that were similar in elevation.

Differences between the 15 stages of the stage-discharge relation (rating curve 43.1; NAVD 88 stages 15.2 to $29.2 \mathrm{ft}$ ) and the simulated water-surface elevations at the Pawtuxet River streamgage ranged from -0.68 to $0.80 \mathrm{ft}$ (table 5). The average and median differences between the 15 stages and simulated water-surface elevations were -0.10 and $-0.11 \mathrm{ft}$, respectively. Absolute differences were $0.5 \mathrm{ft}$ or less for $10 \mathrm{of}$ the 15 stages and between 0.5 and less than $0.8 \mathrm{ft}$ for the other 5 stages.

Differences between surveyed and simulated watersurface elevations of 27 selected HWMs in the study reach for the March 31, 2010, flood ranged from -1.99 to $1.78 \mathrm{ft}$ (table $6)$. The average and median differences between surveyed and simulated water-surface elevations for the $27 \mathrm{HWMs}$ were -0.12 and $0.07 \mathrm{ft}$, respectively. Absolute differences were $0.5 \mathrm{ft}$ or less for 13 of the $27 \mathrm{HWMs}$, between 0.5 and $1.0 \mathrm{ft}$ for 7 of the $27 \mathrm{HWMs}$, and between 1.0 and $2.0 \mathrm{ft}$ for 7 of the 27 HWMs. Field crews can sometimes collect a HWM that is lower than the peak water-surface elevation of a flood because more than one line of marks can be left by debris, seeds, and mud as floodwaters recede (Feaster and Koenig, 2017). This is likely the case with HWMs USGS-123 and USGS-125 because both have simulated water-surface elevations that are almost $2 \mathrm{ft}$ higher than the surveyed HWM elevations. Overall, the results demonstrate that the model is capable of simulating accurate water levels over a wide range of flows in the Pawtuxet River study reach.
Table 5. Differences between 15 simulated water-surface elevations and stage elevations at 1 -foot intervals from 8.0 to 22.0 feet for U.S. Geological Survey Pawtuxet River at Cranston, Rhode Island, streamgage 01116500.

[ft, foot; NAVD 88, North American Vertical Datum of 1988]

\begin{tabular}{cccc}
\hline $\begin{array}{c}\text { Stage, } \\
\text { in ft referenced } \\
\text { to the gage } \\
\text { datum }\end{array}$ & $\begin{array}{c}\text { Stage } \\
\text { elevation, } \\
\text { in ft above } \\
\text { NAVD 88 }\end{array}$ & $\begin{array}{c}\text { Simulated } \\
\text { water-surface } \\
\text { elevation, } \\
\text { in ft above } \\
\text { NAVD 88 }\end{array}$ & $\begin{array}{c}\text { Difference in } \\
\text { elevation, } \\
\text { in ft }\end{array}$ \\
\hline 8.00 & 15.20 & 15.78 & 0.58 \\
9.00 & 16.20 & 16.43 & 0.23 \\
10.00 & 17.20 & 17.24 & 0.04 \\
11.00 & 18.20 & 18.12 & -0.08 \\
12.00 & 19.20 & 19.20 & 0.00 \\
13.00 & 20.20 & 20.31 & 0.11 \\
14.00 & 21.20 & 21.10 & -0.10 \\
15.00 & 22.20 & 21.93 & -0.27 \\
16.00 & 23.20 & 22.73 & -0.47 \\
17.00 & 24.20 & 23.52 & -0.68 \\
18.00 & 25.20 & 24.56 & -0.64 \\
19.00 & 26.20 & 25.65 & -0.55 \\
20.00 & 27.20 & 26.73 & -0.47 \\
21.00 & 28.20 & 28.05 & -0.15 \\
22.00 & 29.20 & 30.00 & 0.80 \\
\hline
\end{tabular}

\section{Development of Water-Surface Profiles}

The calibrated hydraulic model was used to simulate water-surface profiles for 15 stages at $1-\mathrm{ft}$ intervals between 8.0 and $22.0 \mathrm{ft}$ as referenced to the local datum of the Pawtuxet River at Cranston streamgage (01116500; table 7). These stages correspond to elevations of $15.2 \mathrm{ft}$ and $29.2 \mathrm{ft}$, NAVD 88, respectively. Discharges corresponding to the various stages were obtained from the current (2018) stagedischarge relation (rating curve 43.1) for the Pawtuxet River at Cranston streamgage (table 3). The mapped stages were selected because the NWS AHPS's flood category "action stage" is $8.0 \mathrm{ft}$ (National Weather Service, 2016) and because the stage of $22.0 \mathrm{ft}$ is higher than the peak of the March 31, 2010 , flood and is the upper limit of the current stage-discharge relation. The stage of $22.0 \mathrm{ft}$ is $9.0 \mathrm{ft}$ higher than the NWS AHPS's flood category "major flood stage" of $13.0 \mathrm{ft}$ (National Weather Service, 2016). 
Table 6. Differences between the hydraulic model simulated water-surface elevations for the March 31, 2010, floodflows and the surveyed high-water-mark elevations on the Pawtuxet River in West Warwick, Warwick, and Cranston, Rhode Island.

[HWM, high-water mark; NAVD 88, North American Vertical Datum of 1988; USGS, U.S. Geological Survey; ACE, U.S. Army Corps of Engineers]

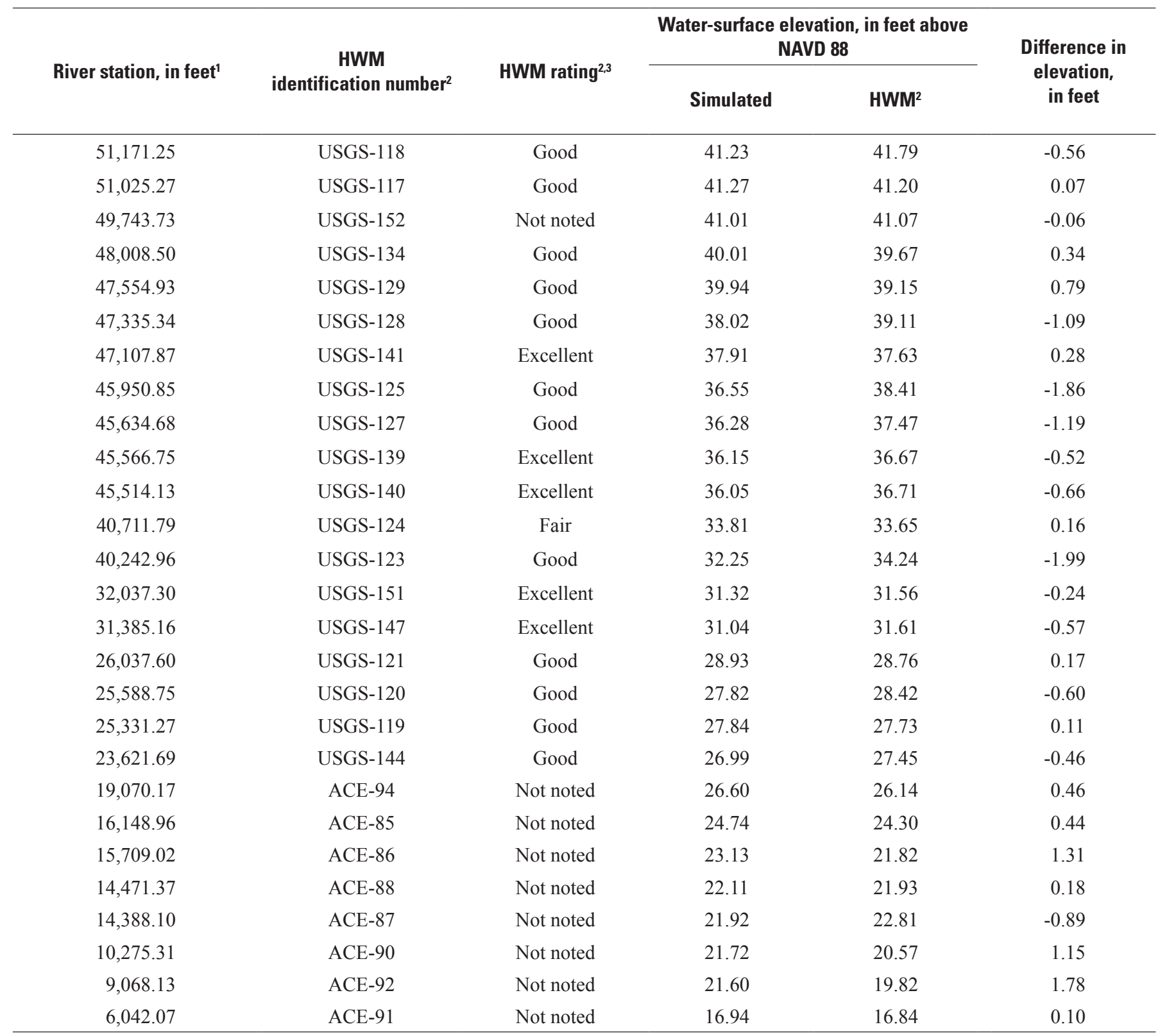

"River station" references the distance upstream to the downstream side of the structure from the most downstream point (starting point) in the hydraulic model.

${ }^{2} \mathrm{HWM}$ information from Zarriello and Bent (2011).

${ }^{3}$ Rating of HWMs from Koenig and others (2016, table 2). 
Table 7. Stage, discharge, and approximate annual exceedance probability at U.S. Geological Survey Pawtuxet River at Cranston, Rhode Island, streamgage 01116500 for profiles mapped on the Pawtuxet River in West Warwick, Warwick, and Cranston, Rhode Island.

[ft, foot; NAVD 88, North American Vertical Datum of 1988; $\mathrm{ft}^{3} / \mathrm{s}$, cubic foot per second; NA, not applicable]

\begin{tabular}{|c|c|c|c|c|}
\hline Grid identification' ${ }^{1}$ & $\begin{array}{l}\text { Stage, in ft referenced } \\
\text { to gage datum }\end{array}$ & $\begin{array}{l}\text { Stage elevation, } \\
\text { in } \mathrm{ft} \text { above NAVD } 88\end{array}$ & Discharge, in $\mathrm{ft}^{3} / \mathrm{s}$ & $\begin{array}{l}\text { Closest floodflow's annual } \\
\text { exceedance probability, } \\
\text { in percent }{ }^{2}\end{array}$ \\
\hline PawtuxetRI_01 & 8.00 & 15.20 & 1,360 & NA \\
\hline PawtuxetRI_02 & 9.00 & 16.20 & 1,710 & 50 \\
\hline PawtuxetRI_03 & 10.00 & 17.20 & 2,150 & NA \\
\hline PawtuxetRI_04 & 11.00 & 18.20 & 2,660 & 20 \\
\hline PawtuxetRI_05 & 12.00 & 19.20 & 3,300 & NA \\
\hline PawtuxetRI_06 & 13.00 & 20.20 & 4,050 & 10 \\
\hline PawtuxetRI_07 & 14.00 & 21.20 & 4,850 & 4 \\
\hline PawtuxetRI_08 & 15.00 & 22.20 & 5,900 & 2 \\
\hline PawtuxetRI_09 & 16.00 & 23.20 & 7,000 & NA \\
\hline PawtuxetRI_10 & 17.00 & 24.20 & 8,300 & 1 \\
\hline PawtuxetRI_11 & 18.00 & 25.20 & 9,824 & 0.5 \\
\hline PawtuxetRI_12 & 19.00 & 26.20 & 11,500 & NA \\
\hline PawtuxetRI_13 & 20.00 & 27.20 & 13,340 & 0.2 \\
\hline${ }^{3}$ PawtuxetRI_14 & 21.00 & 28.20 & 15,330 & NA \\
\hline PawtuxetRI_15 & 22.00 & 29.20 & 17,500 & NA \\
\hline
\end{tabular}

\section{Flood-Inundation Maps}

Flood-inundation maps were created in a GIS for the 15 water-surface profiles by combining the profiles and DEM data. The maps depict the flood-inundation extent (flood-plain boundaries) of flood stages from 8.0 to $22.0 \mathrm{ft}$ (gage datum) at the Pawtuxet River streamgage. The flood map corresponding to the simulated water-surface profile at a stage of $21.0 \mathrm{ft}$ is presented in figure 3; the stage of this map is the closest to the March 31, 2010, flood stage of $20.79 \mathrm{ft}$. The water-surface elevations of the lower part of the Pawtuxet River study reach (the most downstream approximately 6,000 ft of reach) from about U.S. Rt. 1A/State Rt. 117/Warwick Avenue to Pawtuxet Cove (about $330 \mathrm{ft}$ downstream from the Broad Street bridge; fig. 1) could be affected by tidal backwater from high tides in Narragansett Bay. However, several field observations appear to show that for flows greater about $1,000 \mathrm{ft}^{3} / \mathrm{s}$ (stage of about $6.83 \mathrm{ft}$ at gage datum) at the Pawtuxet River streamgage, there is little to no effect of tidal backwater at normal (non-storm affected) high tide upstream from the former Pawtuxet Falls dam, which was located about $100 \mathrm{ft}$ upstream from the Broad Street bridge (Andrew Massey, U.S. Geological Survey, oral commun., 2016). The flood-inundation maps depict only riverine flooding and do not depict any tidal backwater or coastal storm surge that might occur in the lower part of the river reach.

The DEM data were derived from the same lidar data described previously in the section "Topographic and Bathymetric Data" and have an estimated vertical accuracy of $\pm 1 \mathrm{ft}$. Estimated flood-inundation boundaries for each simulated profile were developed with HEC-GeoRAS software (U.S. Army Corps of Engineers, 2009), which enables the preparation of geometric data for import into HEC-RAS software and processes simulation results exported from HEC-RAS (U.S. Army Corps of Engineers, 2016). Shapefile polygons and depth grids of the inundated areas for each profile were modified, as required, in the ArcMap application of ArcGIS (Esri, 


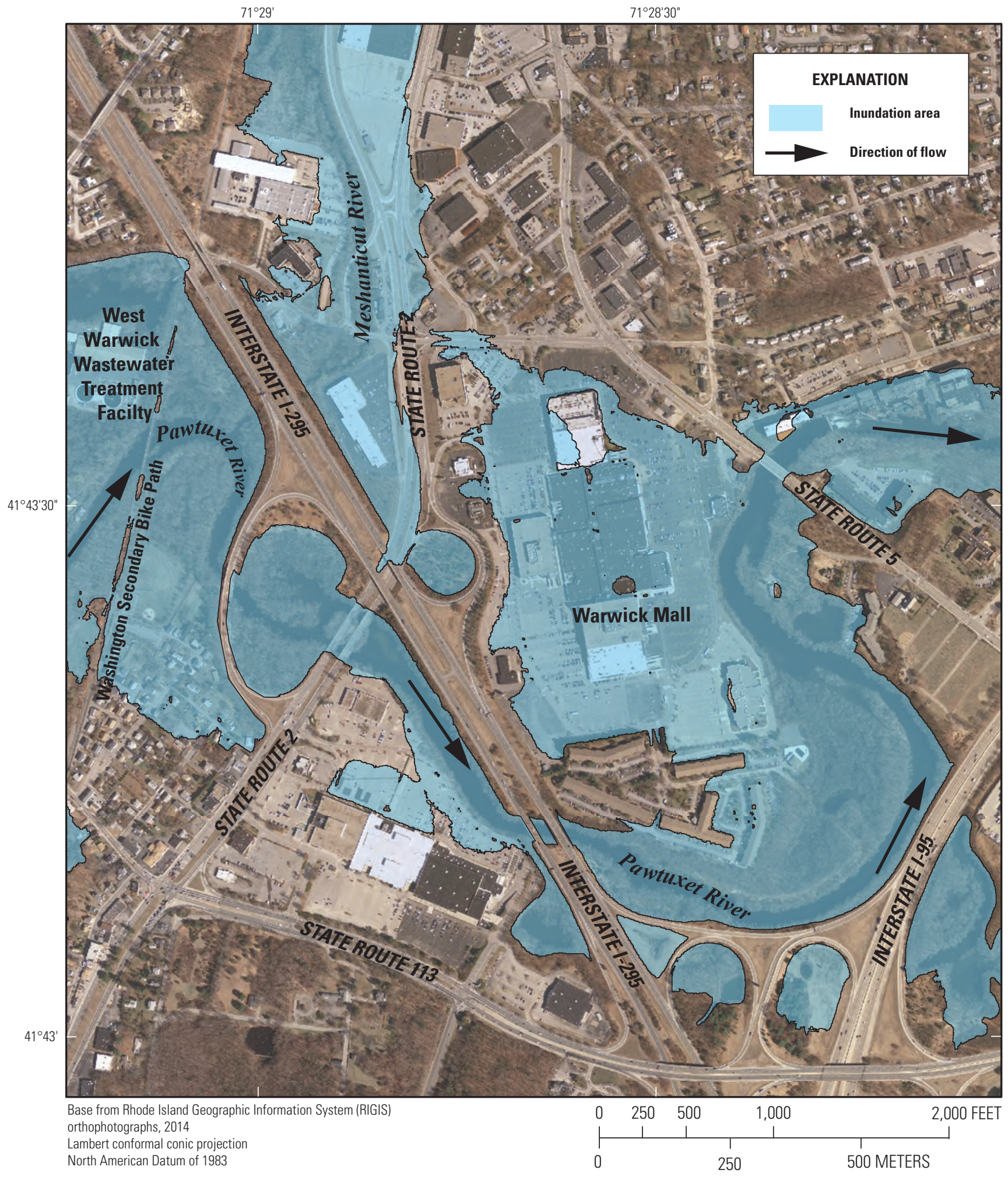

Figure 3. Flood-inundation map for a reach of the Pawtuxet River in Warwick, Rhode Island, corresponding to a stage of 21.0 feet, gage datum, approximately depicting the March 31, 2010, peak flood stage of 20.79 feet at U.S. Geological Survey Pawtuxet River at Cranston, Rhode Island, streamgage 01116500. Gage datum of 21.0 feet is 28.2 feet, North American Vertical Datum of 1988. (Location of streamgage 01116500 is shown in figure 1.) 
2016) to ensure a hydraulically reasonable transition of the flood boundaries between modeled cross sections.

The flood-inundation areas are overlaid on high-resolution, geospatially referenced aerial photographs of the study area (fig. 3). Any inundated areas that were detached from the main channel were examined to identify subsurface connections with the main river, such as through culverts under roadways. Where such connections existed, the mapped inundated areas were retained in their respective flood maps; otherwise, the erroneously delineated parts of the flood extent were deleted. Bridge surfaces are shown as noninundated up to the lowest flood stage that either intersects the lowest structural chord of the bridge or completely inundates one or both approaches to the bridge. Where the lowest flood stage either intersects the lowest structural chord of the bridge or completely inundates one or both approaches to the bridge, the bridge surface is depicted as being inundated. A shaded building should not be interpreted to mean that the structure is completely submerged but rather that bare-earth surfaces in the vicinity of the building are inundated, and the water depth (as indicated in the mapping application by hovering the cursor over the inundated area) near the building would be an estimate of the water level inside the structure, unless flood-proofing measures had been implemented. Estimates of water depth can be obtained from the depth-grid data that are included with the presentation of the flood maps on an interactive USGS mapping application described in the "Flood-Inundation Map Delivery" section.

\section{Flood-Inundation Map Delivery}

The USGS Flood Inundation Mapping Science website at (https://water.usgs.gov/osw/flood_inundation) makes USGS flood-inundation study information available to the public through a mapping application that presents map libraries and provides detailed information on flood extents and depths for modeled sites in the United States. The mapping application helps users produce customized flood-inundation maps from the map library through a print-on-demand feature that allows the user to zoom to the area of interest, choose the desired stage, and print only that part of the map (for example, fig. 3). The flood-inundation maps are displayed in sufficient enough detail that preparations for flooding and decisions for emergency response can be made efficiently.

The mapping application provides a link to the USGS NWIS website (U.S. Geological Survey, 2016), which presents the current (real-time) stage and streamflow at the Pawtuxet River streamgage (01116500) to which the inundation maps are referenced. A second link connects to the NWS AHPS website for the streamgage (CRAR1; National Weather Service, 2016) so that the user can obtain applicable information on the forecasted stage at the streamgage.

All GIS files presented on the USGS Flood Inundation Mapping Science website and metadata associated with each of the files are available as a USGS data release (Bent and Lombard, 2018).

\section{Disclaimer For Flood-Inundation Maps}

The flood-inundation maps should not be used for navigation, regulatory, permitting, or other legal purposes. The USGS provides these maps "as-is" for a quick reference, emergency planning tool but assumes no legal liability or responsibility resulting from the use of this information.

\section{Uncertainties and Limitations Regarding Use of Flood-Inundation Maps}

Although the flood-inundation maps represent the boundaries of inundated areas with a distinct line, some uncertainty is associated with these maps. There are uncertainties associated with the hydrology, the model, the observed water surfaces, and the mapping. The flood boundaries shown were estimated on the basis of flood stages and streamflows at the Pawtuxet River streamgage. There are errors associated with the stage-discharge rating curves used to estimate flow at the streamgages because the rating curve is smoothed through the streamflow measurements and the concurrent stage. Estimates of flow were computed for areas upstream and downstream from the streamgage by using the estimates of flows at the streamgage and adjusting them for the change in drainage area from the streamgage to the new location. Meteorological factors, such as the timing and distribution of precipitation, may cause actual streamflows along the modeled reach to vary from those assumed during a flood, which may lead to variations in the water-surface elevations and inundation boundaries shown on the maps.

Water-surface elevations along the stream reaches were estimated by using steady-state hydraulic modeling, assuming unobstructed flow, and using streamflows and hydrologic conditions anticipated at the streamgage. The hydraulic model reflects the land-cover characteristics and any bridge, dam, levee, or other hydraulic structure present as of September 2017. The HEC-RAS model is a one-dimensional hydraulic model and, as such, cannot always capture everything that occurs during a flood. Additional areas may be flooded as a result of unanticipated conditions, such as changes in the streambed elevation or roughness, backwater into major tributaries along a main-stem river, or backwater from localized debris. HEC-RAS models are more accurate when they are calibrated to flows from streamgages and to HWMs collected after flooding events. The HWMs collected in the field are from actual events and are given a rating from poor $( \pm 0.4 \mathrm{ft}$ of perceived difference between the field-identified elevation and the actual water-surface elevation during the event) to excellent ( $\pm 0.05 \mathrm{ft}$ ) (table 2 of Koenig and others, 2016) at the time they are collected (table 6). Ratings of the HWMs often reflect the quality of the HWM itself and do not always take into account when the mark occurred during a storm; some very clear HWMs can occur on the recession of a flood, when the stage holds steady for a time. Thus, the models are as good as the data to which they are calibrated. 
The accuracy of the floodwater extent portrayed on these maps will vary with the accuracy of the DEM used to simulate the land surface. Thus, the mapping of the flood boundaries and the depths of the inundated areas on the maps have some uncertainty. Additionally, the flood-inundation maps depict only riverine flooding and do not depict any tidal backwater or coastal storm surge that might occur in the lower part of the river reach during a flood.

If this series of flood-inundation maps will be used in conjunction with NWS river forecasts, the user should be aware of additional uncertainties that may be inherent in, or factored into, NWS forecast procedures. The NWS uses forecast models to estimate the quantity and timing of water flowing through selected stream reaches in the United States. These forecast models (1) estimate the amount of runoff generated by precipitation and snowmelt, (2) simulate the movement of floodwater as it proceeds downstream, and (3) predict the flow and stage (and water-surface elevation) for the stream at a given location (NWS AHPS forecast point; National Weather Service, undated) throughout the forecast period (typically every 6 hours and 3 to 5 days out in many locations).

\section{Summary}

A series of 15 digital flood-inundation maps was developed by the U.S. Geological Survey (USGS), in cooperation with the Rhode Island Emergency Management Agency and the U.S. Army Corps of Engineers, for the Pawtuxet River in the municipalities of Cranston, Warwick, and West Warwick, Rhode Island. The maps cover a reach about 10.2 miles long downstream from Natick Pond dam (near State Rt. 33/ Providence Street), West Warwick, to the mouth of the river at Pawtuxet Cove (downstream from Broad Street bridge) at Cranston and Warwick. The maps were developed by using U.S. Army Corps of Engineers Hydrologic Engineering Center's River Analysis System (HEC-RAS) and HEC-GeoRAS software to compute water-surface profiles and to delineate estimated flood-inundation areas and depths of flooding for selected stream stages.

Flood profiles were computed for this reach of the Pawtuxet River by means of a one-dimensional step-backwater HEC-RAS hydraulic model created and calibrated as part of an update to Federal Emergency Management Agency Flood Insurance Studies for Kent and Providence Counties (Federal Emergency Management Agency, 2015a and 2015b). The model was updated to reflect the removal of the Pawtuxet Falls dam during August 2011 and the raised elevation of a levee surrounding the Warwick Sewer Authority wastewater treatment facility during 2014-17. The hydraulic model was calibrated to the current (2018) stage-discharge relation (rating curve 43.1) at the USGS Pawtuxet River at Cranston, R.I., streamgage (01116500) and to the peak water-surface elevations (high-water marks) from the March 31, 2010, flood along the 10.2-mile reach. The March 31, 2010, peak flow at the Pawtuxet River streamgage was greater than the estimated 0.2-percent annual exceedance probability floodflow.

The hydraulic model was used to simulate 15 water-surface profiles for flood stages at 1-foot (ft) intervals referenced to the gage datum and ranging from $8.0 \mathrm{ft}(15.2 \mathrm{ft}$, North American Vertical Datum of 1988), which is the National Weather Service (NWS) Advanced Hydrologic Prediction Service's (AHPS) flood category "action stage," to $22.0 \mathrm{ft}$ (29.2 ft, North American Vertical Datum of 1988), which exceeds the maximum recorded stage (20.79 ft, March 31, 2010) and the NWS AHPS's flood category "major flood stage" (13.0 ft). The 15 simulated water-surface profiles do not account for any effect from tidal backwater or coastal storm surge in the lower part of the river reach that might occur during a flood. The water-surface profiles depict riverine flooding only, such as the late February through early April 2010 flooding.

The 15 water-surface profiles were then combined with a geographic information system digital elevation model derived from light detection and ranging (lidar) data to delineate estimated flood-inundation areas as shapefile polygons and depth grids for each profile. These flood-inundation polygons were overlaid on high-resolution, georeferenced aerial photographs of the study area. The flood maps are available through a mapping application that can be accessed on the USGS Flood Inundation Mapping Science website (http://water.usgs.gov/ osw/flood_inundation). Within this mapping application, users can click within the flood-inundation areas for a general indication of depth of water at any point on the maps. These maps, in conjunction with the real-time stage data for the USGS Pawtuxet River at Cranston, R.I., streamgage (01116500) from the National Water Information System and forecasted stage data from the NWS AHPS (CRAR1), will help to guide the general public in taking individual safety precautions and will provide emergency management personnel with a tool to efficiently manage emergency flood operations and postflood recovery efforts. The flood-inundation maps are nonregulatory but provide Federal, State, and local agencies and the public with estimates of the potential extent of flooding during flood events.

\section{References Cited}

Bent, G.C., and Lombard, P.J., 2018, Flood-inundation grids and shapefiles for the Pawtuxet River in West Warwick, Warwick, and Cranston, Rhode Island: U.S. Geological Survey data release, https://doi.org/10.5066/F78C9V6B. 
Brown University, 2011, The floods of March 2010-What have we learned?: Providence, R.I., Brown University, Center for Environmental Studies, 92 p., accessed August 25, 2017, at http://citeseerx.ist.psu.edu/viewdoc/download?doi= 10.1.1.648.5078\&rep=rep1\&type $=$ pdf.

EA Engineering, Science, and Technology, Inc., 2010, Pawtuxet River restoration project-Pawtuxet River, Cranston and Warwick, Rhode Island-Application to alter: Warwick, R.I., EA Project No. 62277.01, 63 p.

England, J.F., Jr., Cohn, T.A., Faber, B.A., Stedinger, J.R., Thomas, W.O., Jr., Veilleux, A.G., Kiang, J.E., and Mason, R.R., Jr., 2018, Guidelines for determining flood flow frequency-Bulletin 17C: U.S. Geological Survey Techniques and Methods, book 4, chap. B5, 148 p., accessed March 30, 2018, at https://doi.org/10.3133/tm4B5.

Esri, 2016, ArcGIS: Esri software, accessed August 11, 2016, at http://www.esri.com/software/arcgis/.

Feaster, T.D., and Koenig, T.A, 2017, Field manual for identifying and preserving high-water mark data: U.S. Geological Survey Open-File Report 2017-1105, 67 p., accessed October 31, 2017, at https://doi.org/10.3133/ofr20171105.

Federal Emergency Management Agency (FEMA), 2015a, Flood Insurance Study - Kent County, Rhode Island (all jurisdictions), revised October 2, 2015: FEMA Flood Insurance Study no. 44003CV000C, 1 v., 87 p., 78 flood profiles.

Federal Emergency Management Agency (FEMA), 2015b; Flood Insurance Study - Providence County, Rhode Island (all jurisdictions), revised October 2, 2015: FEMA Flood Insurance Study no. 44007CV001C, 3 v., 147 p., 209 flood profiles.

Johnstone, D., and Cross, W.P., 1949, Elements of applied hydrology: New York, Ronald Press Co., 276 p.

Kleinschmidt Energy and Water Resource Consultants, 2005, Pawtuxet River anadromous fish passage restoration project feasibility study: Essex, Conn., Kleinschmidt, 96 p.

Koenig, T.A., Bruce, J.L., O’Connor, J.E., McGee, B.D., Holmes, R.R., Jr., Hollins, R., Forbes, B.T., Kohn, M.S., Schellekens, M.F., Martin, Z.W., and Peppler, M.C., 2016, Identifying and preserving high-water mark data: U.S. Geological Survey Techniques and Methods, book 3, chap. A24, 47 p., accessed May 3, 2017, at https://doi.org/10.3133/tm3A24.

Milone \& MacBroom, Inc., 2008, Pawtuxet River restoration alternatives assessment: Cheshire, Conn., Milone \& MacBroom MMI \#3020-01-2, 36 p.
National Oceanic and Atmospheric Administration, 2010, National Centers for Environmental Information, Providence T.F. Green Airport, Warwick, RI, Global Historical Climatology Network-Daily (GHCND) Number: USW00014765: National Oceanic and Atmospheric Administration precipitation data, accessed January 3, 2017, at https://www.ncdc.noaa.gov/cdo-web/datasets/GHCND/ stations/GHCND:USW00014765/detail.

National Oceanic and Atmospheric Administration, 2013a, 2011 U.S. Geological Survey topographic LiDAR - LiDAR for the North East: National Oceanic and Atmospheric Administration metadata, accessed May 30, 2018, at https://coast.noaa.gov/htdata/lidar1_z/geoid12a/data/2524/ ne2011_usgs_lftne_metadata.html.

National Oceanic and Atmospheric Administration, 2013b, State of Rhode Island (classified LAS): LIDAR for the North East-ARRA and LiDAR for the North East part II: National Oceanic and Atmospheric Administration metadata, accessed May 3, 2017, at https://coast.noaa.gov/htdata/ lidar1_z/geoid12a/data/2524/supplemental/ne2011_usgs_ lftneRI.xml.

National Weather Service, 2016, Advanced Hydrologic Prediction Service, Pawtuxet River at Cranston, Rhode Island: National Weather Service website, accessed August 10, 2016, at http://water.weather.gov/ahps2/hydrograph. php?wfo=box\&gage $=$ crar1 .

National Weather Service, [undated], A brief overview of the NWS precipitation and river forecasting and the river forecast on the AHPS hydrograph: National Oceanic and Atmospheric Administration, 1 p., accessed October 7, 2017, at http://water.weather.gov/ahps/pcpn_and_river_forecasting. pdf.

Rhode Island Coastal Resources Management Council, 2017, RI shoreline change special area management planSTORMTOOLS: Rhode Island Shoreline Change Special Area Management Plan website, accessed May 1, 2017, at http://www.beachsamp.org/stormtools/.

Snyder, G.I., Sugarbaker, L.J., Jason, A.L., and Maune, D.F., 2014, National requirements for enhanced elevation data: U.S. Geological Survey Open-File Report 2013-1237, 371 p., accessed October 16, 2014, at http://dx.doi.org/10.3133/ ofr20131237.

U.S. Army Corps of Engineers, Hydrologic Engineering Center, 2009, HEC-GeoRAS, GIS Tools for Support of HECRAS using ArcGIS, User's Manual (ver. 4.2): U.S. Army Corps of Engineers CPD-83 [variously paged]. 
U.S. Army Corps of Engineers, Hydrologic Engineering Center, 2016, HEC-RAS River Analysis System, Hydraulic Reference Manual (ver. 5.0): U.S. Army Corps of Engineers CPD-69 [variously paged].

U.S. Census Bureau, 2016, Quickfacts: U.S. Census Bureau population data, accessed August 27, 2017, at https://www.census.gov/quickfacts/fact/table/US/ PST045216.

U.S. Geological Survey, 2016, USGS 01116500 Pawtuxet River at Cranston, RI in USGS water data for the Nation: U.S. Geological Survey National Water Information System database, accessed August 8, 2016, at http://waterdata.usgs.gov/nwis/inventory/?site no $=01116500 \&$ agency_cd=USGS.
Zarriello, P.J., Ahearn, E.A., and Levin, S.B., 2012, Magnitude of flood flows for selected annual exceedance probabilities in Rhode Island, through 2010: U.S. Geological Survey Scientific Investigations Report 2012-5109, 93 p. [Also available at http://pubs.usgs.gov/sir/2012/5109/.]

Zarriello, P.J., and Bent, G.C., 2011, Elevation of the MarchApril 2010 flood high water in selected river reaches in Rhode Island: U.S. Geological Survey Open-File Report 2011-1029, 34 p. [Also available at http://pubs.usgs.gov/ ofr/2011/1029/.]

Zarriello, P.J., Olson, S.A., Flynn, R.H., Strauch, K.R., and Murphy, E.A., 2014, Simulated and observed 2010 floodwater elevations in selected river reaches in the Pawtuxet River Basin, Rhode Island: U.S. Geological Survey Scientific Investigations Report 2013-5192, 49 p., accessed May 23, 2017, at http://dx.doi.org/10.3133/sir20135192. 
For more information about this report, contact: Director, New England Water Science Center U.S. Geological Survey

10 Bearfoot Road

Northborough, MA 01532

dc_nweng@usgs.gov

or visit our website at

https://newengland.water.usgs.gov

Publishing support provided by the Pembroke Publishing Service Center 
